\author{
Riccardo POLONI* - Alessio MORELLI**
}

\title{
New or interesting beetles from the Abruzzi region (Central Italy) (Insecta Coleoptera)
}

\begin{abstract}
Riassunto: Coleotteri nuovi o interessanti per l'Abruzzo (Italia centrale) (Insecta Coleoptera).
Vengono presentati i risultati di alcune ricerche sui coleotteri dell'Abruzzo. Vengono trattate tre specie di Cerambycidae particolarmente interessanti dal punto di vista ecologico e faunistico e tre specie (un Cerambycidae e due Scarabaeidae) ancora non riportate per la regione: Agapanthia (Epoptes) cynarae (Germar, 1817), Copris hispanus cavolinii (Petagna, 1792), Triodontella nitidula (Rossi, 1790).
\end{abstract}

\begin{abstract}
New data on the beetle fauna of the Abruzzi region (Central Italy) are presented. New data on ecology and distribution are provided for three species of Cerambycidae previously recorded for the region and three species (one Cerambycidae and two Scarabaeoidea) are recorder for the first time for the region: Agapanthia (Epoptes) cynarae (Germar, 1817), Copris hispanus cavolinii (Petagna, 1792), Triodontella nitidula (Rossi, 1790).
\end{abstract}

Key words: Cerambycidae, Scarabaeidae, Faunistics, Ecology, Palaearctic region.

\section{INTRODUCTION}

Italy is an important hotspot of biodiversity in the Mediterranean (Ruffo \& Stoch, 2005). Central and Southern Italy namely play an important role in European biogeography, having been one of the glacial refugia during the quaternary (Dapporto, 2010; Urbani et al., 2017). Thanks to this richness in biodiversity, discoveries of new species are frequent, including sometimes the discovery of large and eye-catching beetles, such as the recently described longhorn beetle Brachyta petriccionei (Rapuzzi et al., 2019) (Cerambycidae).

The aim of this note is to publish some new data on the beetle fauna of the Abruzzi gathered during the last six years. Examined specimens are housed in the following collections: RP (Riccardo Poloni, Formigine, Italy) and AM (Alessio Morelli, Pescara, Italy). The acronym FEI refers to the Italian entomologists' forum (Forum Entomologi Italiani) that hosts some photos of the specimens listed in this paper.

\section{RESULTS}

Necydalis (Necydalis) ulmi (Chevrolat, 1838)

ReCORDS: Abruzzo (AQ), Beffi, $650 \mathrm{~m}, 1-$ 15.VII.2019, wine traps, R. Poloni legit. One specimen (RP).
Distribution: Europe, Caucasus, Transacaucasia. In Europe its distribution spans from Spain to Poland, including Italy, the Balkans, Romania and Bulgaria (Sama, 2002). The distribution range in Italy spans from the Alps to the Southern Appennines, but it is very fragmented (Sama \& Rapuzzi, 2011; Sama, 2005).

REMARKS: This species is associated with broad-leaf well-grown forests and old trees and is more thermophilous that the only other European species of the genus (Necydalis major Linnaeus). Since well-grown broad-leaf forests are relatively rare in Italy, this species is classified as NT (near threatened) in the Italian IUCN red list of saproxylic beetles (Rapuzzi et al., 2014). In the Abruzzi region oak and broad-leaf forests have a limited extension and are patchy due to the orography of the area (which does not allow the ideal climatic conditions for such kind of forests), to reforestation with conifers and over-grazing by sheep. This is the first record for Abruzzi after the two historical data, i.e. Leoni (1908) and a record in the Costa collection in Portici (Naples) (Rapuzzi \& Sama, 2011). A specimen of N. ulmi was recently posted on the Forum Entomologi Italiani (FEIa) and reported by Sama \& Rapuzzi (2011), however, according to its

\footnotetext{
*Riccardo Poloni, Centre d'Ecologie Fonctionnelle et Evolutive (UMR 5175) CNRS, 1919 Route de Mende, 34293 Montpellier 5 , France. E-mail: riccardo.poloni@gmail.com

${ }^{* *}$ Alessio Morelli, via Martiri Ungheresi 22, 65019 Pianella (PE), Italia. E-mail: alessiomorelli89@libero.it
} 
collector (second author), that specimen could have been mislabeled.

Agapanthia (Epoptes) cynarae (Germar, 1817) ReCords: Abruzzo (PE), Popoli, $42.17^{\circ} \mathrm{N} 13.80^{\circ} \mathrm{E}$, 350 m, 9.VI.2019, R. Poloni legit, 3 specimens (RP). DistRIBUTION: Eastern Europe: from Italy, Balkans, Crete and European Turkey (Sama, 2002). In Italy, known so far from Fiuli-Venezia Giulia, Apulia, Basilicata and Calabria Regions (Sama \& Rapuzzi, 2011). REMARKS: the population from Southern Italy (including probably the population here recorded from Central Italy) could have a transadriatic origin, having colonized the Italian land during the Pliocene when the sea level variation uncovered large portions of land.

The species is chiefly associated with Asteraceae (Sama, 2002), in Abruzzi region we found it on Carduus sp. and Onopordum illyricum. In the same grassland we found Agapanthia (Agapanthia) cardui, Agapanthia (Agapanthia) maculicornis davidi, Agapanthia (Epoptes) villosoviridescens, Agapanthia (Epoptes) sicula malmerendii and Phytoecia (Phytoecia) vulneris vulneris. This is the first record for this species for the Abruzzi region.

\section{Agapanthia (Agapanthia) maculicornis davidi Slàma,} 1986

Records: Abruzzo (PE), Popoli, $42.17^{\circ} \mathrm{N} 13.80^{\circ} \mathrm{E}$, 350 m, 9.VI.2019 R. Poloni legit, 2 specimens (RP), Abruzzo (AQ), Capestrano, 11.VI.2019, A. Morelli legit, 1 specimen (AM).

DisTRIBUTION: This interesting subspecies is endemic to Southern Italy and is currently known from Tuscany, Marche, Abruzzi, Latium, Molise, Apulia and Sicily regions (Sama \& Rapuzzi, 2011).

REMARKS: this species is usually found in grasslands. The host plants recorded for this species so far have been Campanula glomerata, Dianthus superbus and Helianthemum spp (Sama, 2002). We found all the recorded specimens on Carduus sp., likely the host plant species in the aforementioned sites.

Obrium cantharinum (Linnaeus, 1767)

ReCORDS: Abruzzo (AQ), Beffi, $650 \mathrm{~m}, 1$ 15.VII.2019, wine traps, R. Poloni legit, 1 specimen (RP); Abruzzo (PE) Popoli, close to "sorgenti del Pescara", VI.2018, C. Mantoni legit, 1 specimen (RP). DistRIBUTION: widely distributed in the Palaearctic region, Sama (2002) lists Europe, Caucasus, Armenia,
Siberia, Mongolia. In the Abruzzi region the species was known thus far by a single record for Cappelle sul Tavo (PE), 20.VII.2010, O. Pacchioni legit (Sama \& Rapuzzi, 2011).

Remarks: this species usually develops in Populus spp., Salixs pp., Rosa spp. and Quercus spp. (Sama, 2002; Bense, 1995). In the Abruzzi region Omar Pacchioni found it with a wine trap placed between an oak and a poplar (FEIc), Cristina Mantoni collected it using a sweeping net in a moist area with many poplars (Mantoni, comm. pers.), and the first author collected it with a wine trap placed on an oak, with no poplars or willows in the surroundings.

Copris hispanus cavolinii (Petagna, 1792)

RECORDS: Abruzzo (AQ), Ofena, Borgo San Silvestro, $380 \mathrm{~m}, 42^{\circ} 18^{\prime} 06.0^{\prime \prime} \mathrm{N} 13^{\circ} 46^{\prime} 48.1$ 'E, 01.III.2015, A. Morelli legit, 2 specimens (AM)

DisTRIBUTION: In Italy this subspecies occurs through the peninsula and in Sicily, whereas in Sardinia we can find the nominotypical subspecies (Ballerio et al., 2010 ; 2014). Despite the wide distribution through the peninsula, no records for the Abruzzi region have been published thus far.

REMARKS: The specimens were collected in a xeric pasture under sheep dung, at low altitude, characteristics that fit very well with the biology of the species. The species is new to the Abruzzi region and we hypothesize that it could occur in other xeric or Mediterranean environments of the region, such as Popoli, Capestrano and Sulmona.

Triodontella nitidula (Rossi, 1790)

ReCORDS: Abruzzo (PE), Serramonacesca, $790 \mathrm{~m}$, 42 $2^{\circ} 3^{\prime} 38.4^{\prime \prime} \mathrm{N} 14^{\circ} 05^{\prime} 20.2^{\prime}$ 'E, 06.VII.2014, on Poaceae plants, A. Morelli legit, 1 specimen (AM).

Distribution: an Italian endemic, recorded thus far from all the regions of the peninsula (with the exception of Liguria, Marche, Umbria, the Abruzzi and Apulia) and in Sicily (Ballerio et al., 2010; 2014). First record for the Abruzzi region.

\section{AKNOWLEDGEMENTS}

We would like to thank Marco Uliana (Codevigo) who confirmed the identificationof Triodontella nitidula, Stefano Ziani (Meldola) who confirmed the identification of Copris hispanus cavolinii, and Cristina Mantoni (Roma) for letting us to study some material she collected in the Abruzzi region during her $\mathrm{PhD}$. 


\section{REFERENCES}

Ballerio A., Rey A., Uliana M., Rastelli M., Rastelli S., Romano M., Colacurcio L. 2010 - Piccole Faune. Coleotteri Scarabeoidei d'Italia. Marco Serra Tarantola Editore, Brescia. [DVD]

Ballerio A., Rey A., Uliana M., Rastelli M., Rastelli S., Romano M., Colacurcio L. 2014 - Coleotteri Scarabeoidei d'Italia. Available from: http://www.societaentomologicaitaliana.it/Coleotteri\%20Scarabeoidea\%20d'Italia\%202014/scarabeidi/ home.htm (accessed 21 February 2020)

DApporto L., 2010 - Speciation in Mediterranean refugia and post-glacial expansion of Zerynthia polyxena (Lepidoptera, Papilionidae). Journal of Zoological Systematics and Evolutionary Research, 48 (3): 229-237.

LEONI G. 1908 - Appunti sui coleotteri italiani. Rivista di coleotterologia italiana, 6 (6): 137-138.

Rapuzzi P., Biscaccianti A. B., Baviera C., 2014 - Famiglia Cerambycidae. Appendice 1 e schede tecniche on line (www.iucn.it). In: Audisio P., Baviera C., Carpaneto G.M., Biscaccianti A. B., Battistoni A., Teofili C., Rondinini C. (compilatori): Lista Rossa IUCN dei Coleotteri saproxilici Italiani. Comitato Italiano IUCN e Ministero dell'Ambiente e della Tutela del Territorio e del Mare, Roma.

Rapuzzi P., Bologna M.A., Poloni R., 2019 - Brachyta (Fasciobrachyta) petriccionei, a new Longhorn beetle species from Central Italy (Coleoptera: Cerambycidae). Fragmenta entomologica, 51 (1): 97-101.

Ruffo S., Sтосн F., 2005 - Introduzione. In: Ruffo S., Sтосн, F. (eds). Checklist e distribuzione della fauna italiana: 10.000 specie terrestri e delle acque interne. Museo civico di Storia naturale di Verona, pp. 13-14.

SAma G., 2005 - Coleoptera Cerambycidae. In: RufFo S., Stосн, F. (eds.) - Checklist e distribuzione della fauna italiana. Museo civico di Storia naturale di Verona, pp. 219-222.

Urbani F., D’alessandro P., Biondi M., 2017 - Using Maximum Entropy Modeling (MaxEnt) to predict future trends in the distribution of high-altitude endemic insects in response to climate change. Bulletin of Insectology, 70 (2): 189-200. 